\title{
Influence of water availability in the distributions of branched glycerol dialkyl glycerol tetraether in soils of the Iberian Peninsula
}

\author{
J. Menges ${ }^{1}$, C. Huguet ${ }^{2}$, J. M. Alcañiz ${ }^{3,4}$, S. Fietz ${ }^{5}$, D. Sachse ${ }^{1}$, and A. Rosell-Melé2,6 \\ ${ }^{1}$ Institute of Earth and Environmental Sciences, University of Potsdam, 14476 Potsdam-Golm, Germany \\ ${ }^{2}$ Institut de Ciència i Tecnologia Ambientals (ICTA), Universitat Autònoma de Barcelona, 08193 Cerdanyola del Vallès, \\ Catalonia, Spain \\ ${ }^{3}$ Centre de Recerca Ecològica i Aplicacions Forestals (CREAF), 08193 Cerdanyola del Vallès, Catalonia, Spain \\ ${ }^{4}$ Departament de Biología Animal de Biología Vegetal i de Ecologia, Universitat Autònoma de Barcelona, 08193 Cerdanyola \\ del Vallès, Catalonia, Spain \\ ${ }^{5}$ Department of Earth Sciences, Stellenbosch University, 7602 Stellenbosch, Western Cape, South Africa \\ ${ }^{6}$ Institució Catalana de Recerca i Estudis Avançats (ICREA), 08010 Barcelona, Catalonia, Spain
}

Correspondence to: C. Huguet (carme.huguet@uab.cat)

Received: 18 April 2013 - Published in Biogeosciences Discuss.: 3 June 2013

Revised: 27 January 2014 - Accepted: 18 March 2014 - Published: 16 May 2014

\begin{abstract}
The combined application of the MBT (degree of methylation) and CBT (degree of cyclization) indices, based on the distribution of branched glycerol dialkyl glycerol tetraethers (brGDGTs) in soils, has been proposed as a paleoproxy to estimate mean annual temperature (MAT). CBT quantifies the degree of cyclization of brGDGTs and relates to soil $\mathrm{pH}$. MBT and the simplified version MBT' quantify the degree of methylation of brGDGTs and relate to MAT and soil pH. However, other factors such as soil water availability have also been suggested to influence MBT' and possibly restrict the combined application of the MBT' and CBT indices as a paleotemperature proxy. To assess the effect of hydrological conditions on MBT' and CBT, a set of 23 Iberian Peninsula soil samples, covering a MAT range from 10 to $18^{\circ} \mathrm{C}$ and a mean annual precipitation (MAP) range of $405 \mathrm{~mm}$ to $1455 \mathrm{~mm}$, was analyzed. We found that the CBT was indeed significantly correlated with soil $\mathrm{pH}$ in our sample set. In contrast, MBT' was not correlated with MAT but had a significant correlation with the aridity index (AI), a parameter related to water availability in soils. The AI can explain $50 \%$ of the variation of the MBT', and $70 \%$ of the residuals of MAT estimated with the MBT/CBT proxy as compared to instrumentally measured MAT. We propose that, in arid settings, where water may be an ecologically limiting factor, MBT' is influenced by hydrological conditions rather than temperature. Thus, our results suggest that the combi-
\end{abstract}

nation of MBT' and CBT indices should be applied with caution in paleotemperature reconstructions in soils from dry subhumid to hyperarid environments.

\section{Introduction}

Reconstruction of past temperatures beyond the time period covered by instrumental records is required to understand the natural modes of climate variability. However, the reconstruction of continental temperature is particularly challenging as there are few quantitative proxies. There are a number of studies that have used microfossil assemblages based on pollen, diatoms or chironomids preserved in lake sediments to estimate past air or lake water temperatures (e.g., Colinvaux et al., 1996; Lotter et al., 1997; Kurek et al., 2009). A molecular proxy initially developed to estimate past sea surface temperatures has also been shown to be applicable in lake settings, i.e., the long-chain alkenone unsaturation index (e.g., Marlowe et al., 1984; Zink et al., 2001; Toney et al., 2010). In addition, the glycerol dialkyl glycerol tetraethers (GDGTs) have also been applied in marine as well as continental records for the same purpose (e.g., Powers et al., 2004, 2010; Blaga et al., 2009).

The GDGTs are cell membrane lipids of Archaea and Bacteria that are used in paleoenvironmental studies to track, 


\section{a}

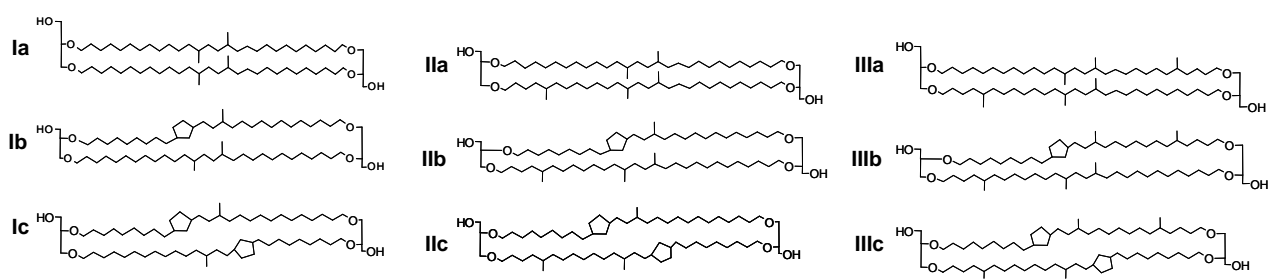

\section{b}

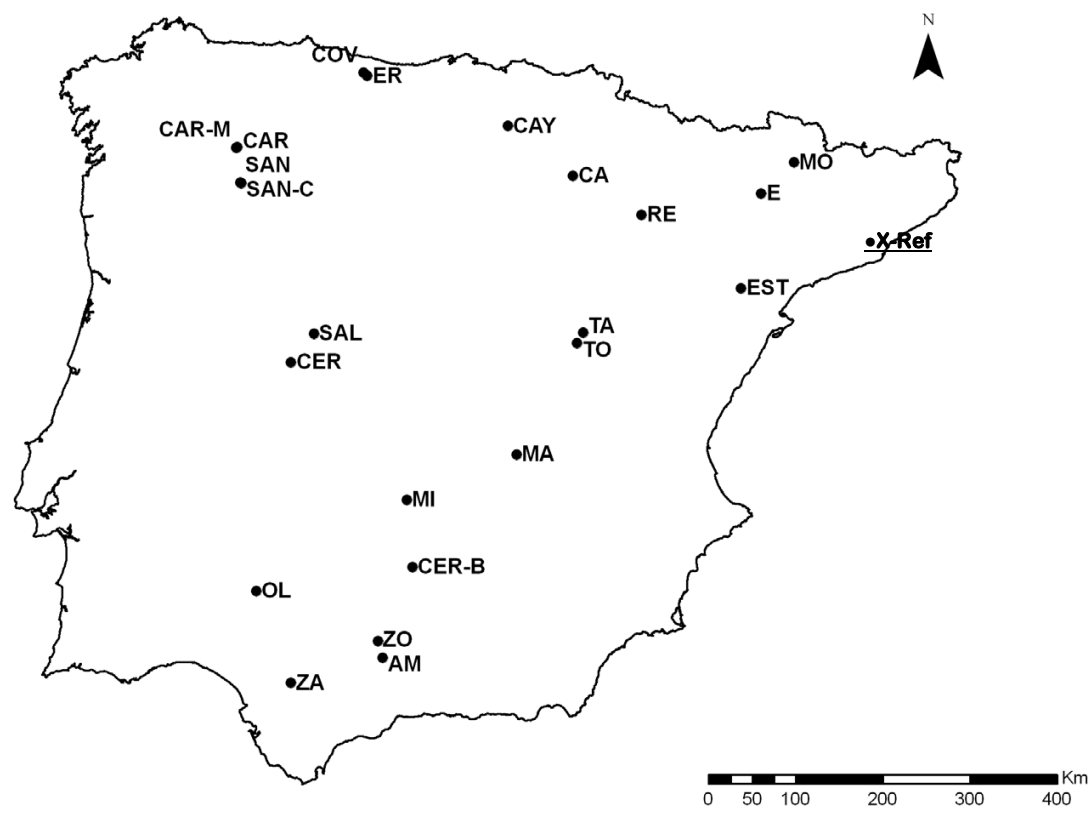

Fig. 1. (a) Chemical structures of brGDGTs discussed in the text, (b) map of the study area with locations of surface soils and sample codes used in this study; standard soil sample X-Ref appears underlined.

for example, changes in archaeal abundance or terrestrial organic matter input into aquatic systems, as well as for estimating past water/air temperatures and soil $\mathrm{pH}$. Two major types of GDGTs are currently used - isoprenoidal (i) and branched (br) - that differ in their alkyl chain structures. iGDGTs are synthesized mainly by aquatic, mesophilic Archaea, while branched glycerol dialkyl glycerol tetraethers (brGDGTs) have been predominantly found in terrestrial settings such as peat bogs and soils (Weijers et al., 2006a), but also in sedimentary settings receiving significant terrestrial input (e.g., Hopmans et al., 2004). The glycerol stereochemistry of the brGDGTs indicates a bacterial provenance (Weijers et al., 2006b), and a brGDGT could be identified in two cultures of Acidobacteria (Sinninghe Damsté et al., 2011). However, brGDGTs are found in a wide range of environments, which can be interpreted as an indication that
brGDGTs may be synthesized by different phyla of Bacteria (Sinninghe-Damsté et al., 2011).

The distribution of brGDGTs in soils has been put forward as a means to estimate past continental mean annual temperatures (MATs) and pH (Weijers et al., 2007). The proxy is derived from measuring two indices that calculate the degree of methylation (MBT and its simplified form MBT') and cyclization (CBT) of brGDGTs (Weijers et al. 2007; Peterse et al., 2012), where

$\mathrm{MBT}=(\mathrm{Ia}+\mathrm{Ib}+\mathrm{Ic}) /(\mathrm{Ia}+\mathrm{Ib}+\mathrm{Ic}+\mathrm{IIa}+\mathrm{IIb}+\mathrm{IIc}+\mathrm{IIIa}+\mathrm{IIIb}+\mathrm{IIIc})$,

$\mathrm{MBT}^{\prime}=(\mathrm{Ia}+\mathrm{Ib}+\mathrm{Ic}) /(\mathrm{Ia}+\mathrm{Ib}+\mathrm{Ic}+\mathrm{IIa}+\mathrm{II} b+\mathrm{IIc}+\mathrm{IIIa})$,

$\mathrm{CBT}=-\log ((\mathrm{Ib}+\mathrm{IIb}) /(\mathrm{Ia}+\mathrm{IIa}))$. 
Roman numerals refer to chemical structures in Fig. 1a. MBT and MBT' have been described to correlate with air temperature and soil $\mathrm{pH}$, while $\mathrm{CBT}$ has been found to depend mainly on soil $\mathrm{pH}$. Thus, using the values of CBT and MBT', one can estimate MAT as follows (Peterse et al., 2012):

$\mathrm{CBT}=3.33-0.38 \times \mathrm{pH}\left(n=114 ; R^{2}=0.70\right)$,

$\mathrm{MAT}=0.81-5.67 \times \mathrm{CBT}+31 \times \mathrm{MBT}^{\prime}\left(n=176 ; R^{2}=0.59\right)$.

The calibration equation to estimate MAT by Peterse et al. (2012), based on MBT' (Eq. 5), has a slightly lower correlation coefficient than the original calibration by Weijers et al. (2007) using MBT. The error of the calibration from both studies is similar, being $5.0^{\circ} \mathrm{C}$ in Peterse et al. (2012) and $4.8^{\circ} \mathrm{C}$ in Weijers et al. (2007). However, the temperature estimates based on the calibration by Peterse et al. (2012) are reported to be generally more consistent with instrumentally measured temperatures.

The combination of the MBT or MBT' and CBT indices has been applied in a variety of marine and freshwater sites to estimate continental MAT (e.g., Weijers et al., 2007; Rueda et al., 2009; Peterse et al., 2012). In these applications the underlying assumption is that brGDGTs in sediments have an allochthonous origin, and the estimated temperatures correspond to those from the nearby continental regions. However, there is circumstantial evidence that brGDGTs are also biosynthesized within lake and ocean basins, not just in soils (e.g., Sinninghe Damsté et al., 2009; Blaga et al., 2010; Tierney et al., 2010; Fietz et al, 2011; Sun et al., 2011). Furthermore, the relatively large scatter in the original MAT calibration data sets (Weijers et al., 2007; Peterse et al., 2012) suggests that other parameters may influence brGDGT indices besides air temperature and soil $\mathrm{pH}$ (e.g., Loomis et al., 2011; Dirghangi et al. 2013; Wang et al., 2013). For instance, brGDGT distributions in geothermally heated soils and in a Spodosol in France were linked to oxygen availability or moistness (Peterse et al., 2009a; Huguet et al., 2010a). Two studies on surface soils from North America showed no correlation between MBT values and MAT, but found a correlation between MBT and mean annual precipitation (MAP) when MAP $<200 \mathrm{~mm}\left(R^{2}=0.75\right)$ (Peterse et al., 2009b) or when MAP $<800 \mathrm{~mm}$ (Dirghangi et al., 2013). This was interpreted as evidence that in arid regions MAP rather than MAT may drive the MBT index variability (Peterse et al., 2009b; Dirghangi et al. 2013). To evaluate further the effect of hydrological conditions on the MBT/CBT proxy, we have analyzed soil samples from locations across the Iberian Peninsula, which represents a range of mainly arid to subarid settings with moderate differences in MATs.

\section{Material and methods}

\subsection{Samples and sites' environmental conditions}

A suite of 23 surface soil samples was collected in October 2010 across the Iberian Peninsula (Fig. 1b). Each soil sample was obtained from the combination of three subsamples taken at least $4 \mathrm{~m}$ apart from each other and within a $10 \mathrm{~m}$ radius area. Subsamples were retrieved after removing the litter and loose gravel if present, scooping the soil from a depth of approximately $10 \mathrm{~cm}$ within a $20 \mathrm{~cm} \times 20 \mathrm{~cm}$ square surface area, and transferring it into an aluminum tray. The soil samples were homogenized and air dried. A subsample of $500 \mathrm{~g}$ was then sieved ( $2 \mathrm{~mm}$ mesh size) removing vegetation remains and small stones.

Sample sites display moderate differences in MAT (10$\left.18^{\circ} \mathrm{C}\right)$, but cover a wide range of MAP $(405-1455 \mathrm{~mm})$ (Fig. 1b, Table 1; Ninyerola et al., 2005). In the Iberian Peninsula, the highest precipitation and cooler temperatures occur generally in the northwest, especially at high elevation, while the driest and warmest areas are in the southeast. A value of the aridity index $(\mathrm{AI}=\mathrm{MAP} /$ mean annual potential evapotranspiration) was calculated for each site using the approach proposed by the Consortium for Spatial Information (CGIAR-CSI) based on UNEP (1997) criteria (Tables 1 and 2; Trabucco and Zomer, 2009). For each site, soil moisture regimes were established according to Soil Survey Staff (2010). In general, the eastern Iberian Peninsula is dominated by soils developed on calcareous parent material or with a significant accumulation of calcium carbonate within the soil profile, while western soils are usually silicic, developed on magmatic or metamorphic rocks, or acidified by leaching. Soils were classified according to the Soil Taxonomy System (Soil Survey Staff, 2010) at group level, as only the surface mineral soil material was collected. The sample set includes a wide range of soil types, belonging to 5 orders and 14 groups, covering a wide range of parent materials, and climatic and geographic conditions (Table 1).

\subsection{Ancillary measurements}

Total organic carbon (TOC) content was determined on finely ground soil samples using a Thermo Flash 1112 elemental analyzer in combustion mode with a Thermo Delta V Advantage mass spectrometer as a detector via a Thermo Conflo III interface, after Werner et al. (1999). A reference compound IAEA 600 was used for external calibration, and to calculate the TOC $\%$ standard deviation, which was \pm 0.25 .

Soil $\mathrm{pH}$ was measured in a soil : de-ionized water suspension $(1: 5)$ by vigorous shaking the mixture for $1 \mathrm{~min}$, and leaving it to settle for $30 \mathrm{~min}$. (Thomas, 1996). A triplicate measurement was taken using a pH meter (GLP22, Crison Instruments) after calibration of the electrode with standard solutions at $\mathrm{pH} 4$ and 7. 
Table 1. Sample code and coordinates, instrumentally measured mean annual temperature $\left(\mathrm{MAT}_{\mathrm{im}}\right)$, instrumentally measured mean annual precipitation $\left(\mathrm{MAP}_{\mathrm{im}}\right)$, aridity index $(\mathrm{AI})$, instrumentally measured $\mathrm{pH}\left(\mathrm{pH}_{\mathrm{im}}\right)$ and $\mathrm{TOC}(\%)$. Soils were classified according to Soil Taxonomy (Soil Survey Staff, 2010) at group level. The calculated CBT and MBT' values, as well as derived $\mathrm{pH}^{\left(\mathrm{pH}_{\mathrm{est}}\right)}$ and MAT (MAT $\mathrm{est}$ ), are also included.

\begin{tabular}{|c|c|c|c|c|c|c|c|c|c|c|c|c|}
\hline Sample & Lat. & Long. & $\begin{array}{r}\mathrm{MAT}_{\mathrm{im}} \\
\left({ }^{\circ} \mathrm{C}\right)\end{array}$ & $\begin{array}{r}\mathrm{MAP}_{\mathrm{im}} \\
(\mathrm{mm})\end{array}$ & AI & $\mathrm{pH}_{\mathrm{im}}$ & $\begin{array}{r}\text { TOC } \\
(\%)\end{array}$ & Soil Group & CBT & MBT' & $\mathrm{pH}_{\mathrm{est}}$ & $\begin{array}{r}\mathrm{MAT}_{\text {est }} \\
\left({ }^{\circ} \mathrm{C}\right)\end{array}$ \\
\hline $\mathrm{AM}$ & 37.32 & -4.62 & 16 & 509 & 0.50 & 8.7 & 3.7 & Calcixerept & 0.53 & 0.21 & 7.3 & 4.3 \\
\hline $\mathrm{CA}$ & 42.26 & -2.09 & 13 & 450 & 0.51 & 7.8 & 2.5 & Torriorthent & 0.29 & 0.08 & 7.9 & 1.6 \\
\hline CAR & 42.49 & -6.78 & 12 & 886 & 0.71 & 7.4 & 9.0 & Endoaquoll & 0.35 & 0.24 & 7.7 & 6.4 \\
\hline CAR-M & 42.49 & -6.79 & 12 & 948 & 0.73 & 6.8 & 3.6 & Eutrudept & 0.79 & 0.38 & 6.6 & 8.1 \\
\hline CAY & 42.78 & -2.99 & 11 & 471 & 0.94 & 6.4 & 10.3 & Calcixeroll & 1.08 & 0.36 & 5.8 & 5.8 \\
\hline CER & 40.32 & -5.93 & 12 & 866 & 0.64 & 4.8 & 18.3 & Dystrudept & n.d. & 0.49 & n.d. & n.d. \\
\hline CER-B & 38.25 & -4.25 & 15 & 771 & 0.45 & 6.4 & 2.3 & Xerorthent & 1.34 & 0.32 & 5.2 & 3.2 \\
\hline COV & 43.30 & -5.04 & 12 & 1455 & 0.97 & 6.7 & 6.3 & Hapludoll & 0.29 & 0.42 & 7.9 & 12.0 \\
\hline $\mathrm{E}$ & 42.03 & -0.53 & 14 & 494 & 0.45 & 8.4 & 5.8 & Calcixerept & 0.33 & 0.21 & 7.8 & 5.5 \\
\hline ER & 43.27 & -4.98 & 10 & 1443 & 1.13 & 5.1 & 6.1 & Dystrudept & 1.71 & 0.59 & 4.2 & 9.4 \\
\hline EST & 41.07 & -0.20 & 14 & 415 & 0.40 & 7.5 & 1.5 & Torriorthent & 0.85 & 0.09 & 6.4 & -1.3 \\
\hline MA & 39.41 & -2.88 & 14 & 416 & 0.35 & 8.1 & 1.3 & Calcixerept & 0.64 & 0.16 & 7.0 & 2.2 \\
\hline MI & 38.94 & -4.34 & 14 & 532 & 0.38 & 6.2 & 2.7 & Haploxeralf & 1.31 & 0.35 & 5.2 & 4.2 \\
\hline MO & 42.33 & 1.00 & 10 & 770 & 1.11 & 6.6 & 7.6 & Haplustoll & 0.63 & 0.34 & 7.0 & 7.8 \\
\hline OL & 37.96 & -6.28 & 16 & 776 & 0.51 & 6.2 & 2.6 & Haplorexept & 1.04 & 0.38 & 5.9 & 6.6 \\
\hline $\mathrm{RE}$ & 41.85 & -1.14 & 15 & 405 & 0.42 & 7.8 & 2.2 & Haplogypsid & 0.78 & 0.09 & 6.6 & -0.9 \\
\hline SAL & 40.62 & -5.63 & 11 & 593 & 0.44 & 6.0 & 3.1 & Haploxeralf & 1.44 & 0.26 & 4.9 & 0.8 \\
\hline SAN & 42.13 & -6.71 & 10 & 1335 & 1.03 & 6.3 & 6.0 & Dystrudept & 1.10 & 0.38 & 5.8 & 6.4 \\
\hline SAN-C & 42.13 & -6.70 & 10 & 1335 & 0.89 & 5.7 & 4.6 & Dystrudept & 1.25 & 0.44 & 5.4 & 7.4 \\
\hline $\mathrm{TA}$ & 40.65 & -1.97 & 10 & 716 & 0.53 & 8.3 & 5.8 & Calcixeroll & 0.35 & 0.15 & 7.7 & 3.3 \\
\hline TO & 40.55 & -2.05 & 11 & 1002 & 0.53 & 8.3 & 7.8 & Haploxeroll & 0.23 & 0.18 & 8.1 & 4.9 \\
\hline ZA & 37.04 & -5.79 & 18 & 611 & 0.50 & 8.4 & 2.6 & Haploxerept & 0.59 & 0.14 & 7.1 & 1.9 \\
\hline $\mathrm{ZO}$ & 37.49 & -4.68 & 17 & 520 & 0.49 & 8.5 & 1.8 & Xerarent & 0.64 & 0.17 & 7.0 & 2.4 \\
\hline
\end{tabular}

\subsection{GDGT analysis}

Samples of approximately $1 \mathrm{~g}$ of dry soil were spiked with an internal standard (GR, Rethoré et al., 2007) and extracted using a microwave (MARS 5-CEM) and dichloromethane (DCM) : methanol $(\mathrm{MeOH})(3: 1, v / v)$. The temperature of the microwave vessels containing the soil aliquots was increased to $70^{\circ} \mathrm{C}$ over $5 \mathrm{~min}$, held at $70^{\circ} \mathrm{C}$ for $5 \mathrm{~min}$ and then decreased to $30^{\circ} \mathrm{C}$. The organic extract was concentrated under a stream of nitrogen, and separated into three fractions of different polarity according to the method in Huguet et al. (2010b). In short, the lipid extract was eluted in a column filled with activated silica using $n$-hexane, $\mathrm{DCM}$ and $\mathrm{MeOH}$. The $\mathrm{MeOH}$ fraction, which contained the GDGTs, was then evaporated under nitrogen, redissolved in $n$-hexane $: n$-propanol $(99: 1, v / v)$ and filtered through $0.45 \mu \mathrm{m}$ PTFE (polytetrafluoroethylene) filters prior to analysis by high-performance liquid chromatography-mass spectrometry (HPLC-MS). The instrumental analysis was performed using a Dionex P680 HPLC system coupled to a Thermo Finnigan Quantum Discovery Max triple sector quadrupole MS with an atmospheric pressure chemical ionization (APCI) interface set in positive mode. Instrumental and chromatographic conditions were adapted from
Schouten et al. (2007), Escala et al. (2009) and Fietz et al. (2011). Extracts were eluted using a Prevail Cyano column $(2.1 \times 150 \mathrm{~mm}, 3 \mathrm{~mm}$; Alltech) fitted with a guard column. The flow rate was set at $0.6 \mathrm{~mL} \times \mathrm{min}^{-1}$, and the HPLC program was as follows: $98.5 \%$ hexane and $1.5 \% n$ propanol for $4 \mathrm{~min}$, increasing the proportion of $n$-propanol to $5 \%$ in $11 \mathrm{~min}$, then to $10 \%$ over $1 \mathrm{~min}$ and held constant for $4 \mathrm{~min}$, finally lowered to $1.5 \%$ in $1 \mathrm{~min}$ and held constant for a further $9 \mathrm{~min}$ prior to injecting the next sample. The parameters of the APCI were set as follows to generate positive ion spectra: corona discharge $3 \mathrm{~mA}$, vaporizer temperature $400^{\circ} \mathrm{C}$, sheath gas pressure $49 \mathrm{mTorr}$, auxiliary gas $\left(\mathrm{N}_{2}\right)$ pressure 5 mTorr, and capillary temperature $200^{\circ} \mathrm{C}$. GDGTs were detected in selected ion monitoring (SIM) mode of $[\mathrm{M}+\mathrm{H}]^{+} \pm 0.5 \mathrm{~m} / \mathrm{z}$ units. Absolute abundances of brGDGTs were quantified by comparison of the corresponding peak areas with those of the internal standard GR and correcting for the response factor (cf. Huguet et al., 2006).

Samples were extracted and measured once. Due to low abundances of brGDGTs IIIb and IIIc (Fig. 1a), we decided to calculate the MBT' rather than MBT index (Peterse et al., 2012). The reproducibility of the measurement of MBT' and CBT was 0.006 and 0.022 , respectively, obtained from the 
Table 2. Sample codes and coordinates, aridity index (AI), individual branched (br) GDGTs' relative abundances (\%) and concentrations of total brGDGTs per total organic carbon (TOC). Abbreviation n.d. denotes not detected.

\begin{tabular}{|c|c|c|c|c|c|c|c|c|c|c|c|c|c|}
\hline \multirow[t]{2}{*}{ Sample } & \multirow[t]{2}{*}{ Lat. } & \multirow[t]{2}{*}{ Long. } & \multirow[t]{2}{*}{ AI } & \multicolumn{9}{|c|}{ Branched GDGTs (\%) } & \multirow{2}{*}{$\begin{array}{r}\text { brGDGTs } \\
\left(\mu \mathrm{gTOC}^{-1}\right)\end{array}$} \\
\hline & & & & Ia & $\mathrm{Ib}$ & Ic & IIa & IIb & IIc & IIIa & IIIb & IIII & \\
\hline $\mathrm{AM}$ & 37.32 & -4.62 & 0.50 & 10.1 & 6.3 & 3.4 & 31.9 & 6.1 & n.d. & 36.6 & 3.9 & 1.8 & 2.0 \\
\hline $\mathrm{CA}$ & 42.26 & -2.09 & 0.51 & 6.7 & n.d. & n.d. & 27.0 & 17.5 & n.d. & 36.3 & 12.4 & n.d. & 1.3 \\
\hline CAR & 42.49 & -6.78 & 0.71 & 14.0 & 8.6 & 1.1 & 37.1 & 14.1 & 1.0 & 21.4 & 2.5 & 0.3 & 17.5 \\
\hline CAR-M & 42.49 & -6.79 & 0.73 & 31.0 & 6.2 & 0.4 & 43.1 & 5.8 & n.d. & 12.6 & 0.9 & n.d. & 4.4 \\
\hline CAY & 42.78 & -2.99 & 0.94 & 32.6 & 2.9 & n.d. & 42.4 & 3.3 & n.d. & 18.1 & 0.6 & n.d. & 7.0 \\
\hline CER & 40.32 & -5.93 & 0.64 & 49.5 & n.d. & n.d. & 41.1 & n.d. & n.d. & 9.4 & n.d. & n.d. & 16.3 \\
\hline CER-B & 38.25 & -4.25 & 0.45 & 30.4 & 1.7 & n.d. & 47.7 & 1.8 & n.d. & 18.4 & n.d. & n.d. & 7.9 \\
\hline $\mathrm{COV}$ & 43.30 & -5.04 & 0.97 & 21.0 & 14.3 & 5.6 & 33.2 & 13.2 & 1.4 & 9.7 & 1.5 & n.d. & 15.4 \\
\hline E & 42.03 & -0.53 & 0.45 & 13.2 & 7.0 & 0.8 & 36.3 & 16.4 & n.d. & 26.3 & n.d. & n.d. & 3.2 \\
\hline ER & 43.27 & -4.98 & 1.13 & 57.3 & 1.8 & n.d. & 34.4 & n.d. & n.d. & 6.5 & n.d. & n.d. & 7.2 \\
\hline EST & 41.07 & -0.20 & 0.40 & 8.7 & n.d. & n.d. & 42.7 & 7.3 & n.d. & 41.4 & n.d. & n.d. & 2.3 \\
\hline MA & 39.41 & -2.88 & 0.35 & 11.9 & 4.4 & n.d. & 35.4 & 6.4 & n.d. & 41.9 & n.d. & n.d. & 3.5 \\
\hline MI & 38.94 & -4.34 & 0.38 & 32.6 & 2.4 & n.d. & 47.0 & 1.4 & n.d. & 16.6 & n.d. & n.d. & 3.5 \\
\hline MO & 42.33 & 1.00 & 1.11 & 25.3 & 7.4 & 1.0 & 40.0 & 8.1 & n.d. & 17.2 & 1.0 & n.d. & 9.6 \\
\hline OL & 37.96 & -6.28 & 0.51 & 33.7 & 4.0 & n.d. & 48.1 & 3.4 & n.d. & 10.7 & n.d. & n.d. & 9.9 \\
\hline $\mathrm{RE}$ & 41.85 & -1.14 & 0.42 & 8.6 & n.d. & n.d. & 42.9 & 8.5 & n.d. & 36.6 & 3.5 & n.d. & 6.1 \\
\hline SAL & 40.62 & -5.63 & 0.44 & 25.2 & 1.2 & n.d. & 51.5 & 1.6 & n.d. & 20.5 & n.d. & n.d. & 3.4 \\
\hline SAN & 42.13 & -6.71 & 1.03 & 34.3 & 3.1 & 0.4 & 44.7 & 3.2 & n.d. & 13.9 & 0.4 & n.d. & 10.8 \\
\hline SAN-C & 42.13 & -6.70 & 0.89 & 41.0 & 2.8 & 0.4 & 43.5 & 1.9 & n.d. & 10.1 & 0.3 & n.d. & 12.2 \\
\hline $\mathrm{TA}$ & 40.65 & -1.97 & 0.53 & 8.7 & 4.8 & 0.7 & 35.5 & 14.7 & n.d. & 33.0 & 2.2 & 0.2 & 3.5 \\
\hline TO & 40.55 & -2.05 & 0.53 & 10.0 & 6.5 & 0.4 & 32.1 & 18.3 & 2.0 & 26.9 & 3.8 & n.d. & 6.5 \\
\hline $\mathrm{ZA}$ & 37.04 & -5.79 & 0.50 & 10.4 & 3.4 & n.d. & 39.6 & 9.5 & n.d. & 34.5 & 2.6 & n.d. & 2.3 \\
\hline $\mathrm{ZO}$ & 37.49 & -4.68 & 0.49 & 11.33 & 5.2 & n.d. & 39.5 & 6.5 & n.d. & 36.0 & 1.4 & n.d. & 2.9 \\
\hline
\end{tabular}

repeated analysis (six times) of a reference soil sample (sample X-Ref in Fig. 1b). The possibility of an apparent correlation between the abundances of GDGTs with MBT' and CBT due to an increased analytical error at low abundances was discarded after recalculating the MBT' and CBT while removing all peak areas below a threshold value. The original and the recalculated MBT' and CBT values did not reveal substantial differences (i.e., their lineal correlation yielded $R^{2}=0.96, R^{2}=0.99$, respectively).

Temperature residuals were calculated by subtracting brGDGT-estimated values for MAT (i.e., $\mathrm{MAT}_{\text {est }}$, using MBT'/CBT) from instrumental values of MAT derived from

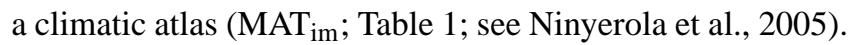
The residuals of $\mathrm{pH}$ values were calculated by subtracting brGDGT estimates (i.e., $\mathrm{pH}_{\mathrm{est}}$, using $\mathrm{CBT}$ ) from soil $\mathrm{pH}$ values measured in the laboratory with a $\mathrm{pH}$ meter $\left(\mathrm{pH}_{\mathrm{im}}\right)$. Throughout the manuscript, the use of the subscript "est" denotes estimated values using GDGT indices, while the subscript "im" refers to values measured with instruments (Table 1, Sect. 2.2).

\section{Results and discussion}

\subsection{BrGDGT abundances and distribution}

The concentrations of brGDGTs in the soils ranged between $1.3 \mu \mathrm{g} \mathrm{g}_{\mathrm{TOC}}^{-1}$ and $17.5 \mu \mathrm{g} \mathrm{g}_{\mathrm{TOC}}^{-1}$ (Table 2). The predominant brGDGT is GDGT IIa, followed by IIIa and Ia (Table 2). The brGDGTs IIIb and c, IIc as well as brGDGT Ic are only present in minor amounts. In eight of the samples (35\% of the total), none of these brGDGTs were detected (Table 2), which is a similar percentage as reported in globally distributed soils (Peterse et al., 2012).

Samples with the highest absolute brGDGT abundances were located in the northern Iberian Peninsula, the area with the highest rainfall and cooler temperatures. Towards the drier and warmer south, the brGDGT abundances gradually decreased (Table 2). The highest brGDGT abundance was found in an Endoaquoll soil (sample code CAR, Tables 1 and 2), a relative singular soil with aquic moisture regime, formed on an alluvial delta with a high TOC content $(15.9 \%)$, and relatively high MAP $_{\text {im }}$ in our data set ( $886 \mathrm{~mm}$; Tables 1 and 2). Soil types Hapludoll (one sample) and Dystrudept (four samples) also had relatively high brGDGT abundances. These soils are also characterized by high MAP im $_{\text {im }}(866-1455 \mathrm{~mm})$ and TOC contents that range between 3.5 and $10 \%$. Therefore, our data suggest that 

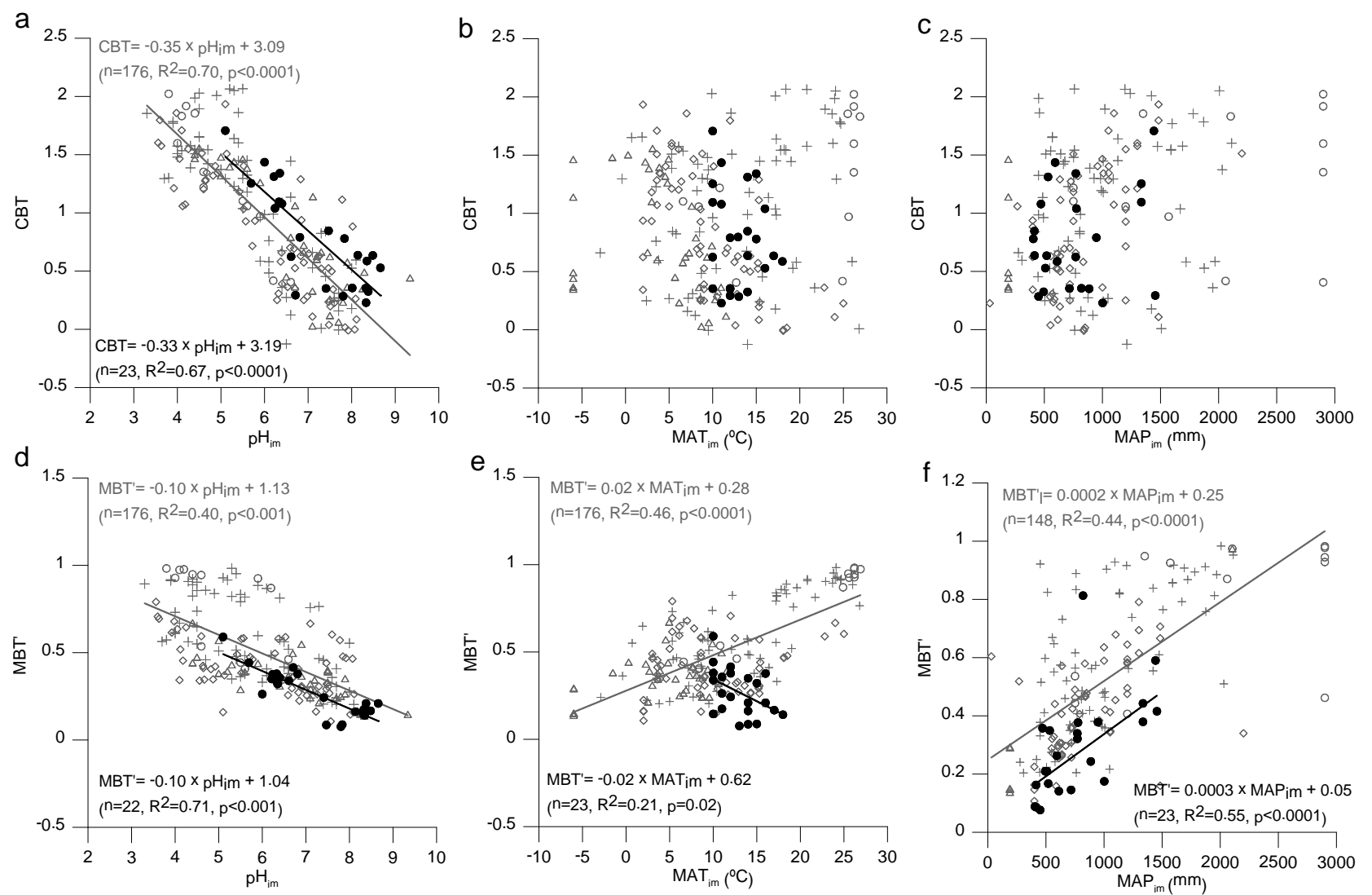

Fig. 2. Linear regression plots of (a) measured soil $\mathrm{pH}\left(\mathrm{pH}_{\mathrm{im}}\right)$ vs. $\mathrm{CBT}$, (b) measured mean annual temperature (MAT $\mathrm{M}_{\mathrm{m}}$; Ninyerola et al.,

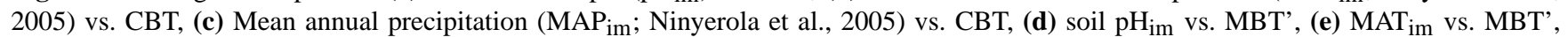
and (f) $\mathrm{MAP}_{\mathrm{im}}$ vs. MBT'. Data compiled by Peterse et al. (2012) are plotted in grey and distinguished by symbols as follows: Weijers et al. (2007) (+), Peterse et al. (2012) $(\diamond)$, Bendle et al. (2010) $(\bigcirc)$ and Peterse et al. (2009b) $(\Delta)$. Data from this study are shown as black circles $(\bullet)$. Linear regression lines, equations, $R^{2}$, and $p$ values are shown in grey for the Peterse et al. (2012) data set and in black for the present study.

brGDGT abundance is partly controlled by both precipitation and to a lower extent by TOC in agreement with previous studies. For instance, a positive correlation was found between soil water content and brGDGT abundances in marsh soils of the Qinghai-Tibetan Plateau (Wang et al., 2013). Soil water content was suggested to have a direct effect on brGDGTs and/or an indirect effect on other factors such as oxygen and TOC content (Wang et al., 2013). Water saturation was also suggested to play a significant role for brGDGT abundance in African soils (Loomis et al., 2011). BrGDGT source organisms have been suggested to be heterotrophic (e.g., Weijers et al., 2010; Huguet et al., 2012; Opperman et al., 2012; Ayari et al., 2013), which could explain the higher brGDGT abundances coupled to high TOC. Earlier studies showed that brGDGT abundances are usually high in water-saturated soils and peat bogs, thus potentially providing an ideal environment for brGDGT source organisms that have been proposed to be anaerobic (Weijers et al., 2006). However, so far, brGDGTs have been identified in only two aerobic Acidobacteria species, suggesting that brGDGTs are synthesized by a range of bacterial communities (Sinninghe Damsté et al., 2011). Hence, the impact of soil redox conditions on brGDGT abundance from diverse bacterial communities has yet to be ascertained.

Our data also indicated that $\mathrm{pH}$ is not a driving factor for brGDGT abundance as, despite covering a $\mathrm{pH}$ range from 4.8 to 8.7 , we did not observe an increase in brGDGTs with lower $\mathrm{pH}$. This contrasts with earlier findings (e.g Peterse et al., 2010; Sinnghe-Damsté et al., 2011; Yang et al., 2011) again suggesting that brGDGTs are produced by a range of bacterial communities.

\subsection{CBT and MBT' relationship with $\mathrm{pH}$ and temperature}

In the soils studied, the CBT values range from 0.23 to 1.71 with an average of 0.81 (Table 1). Even though this is a regional study, our CBT values span almost $70 \%$ of the range of values published in the global calibration set (Weijers et al. 2007). CBT values and $\mathrm{pH}_{\mathrm{im}}$ of the Iberian soils are linearly 
a

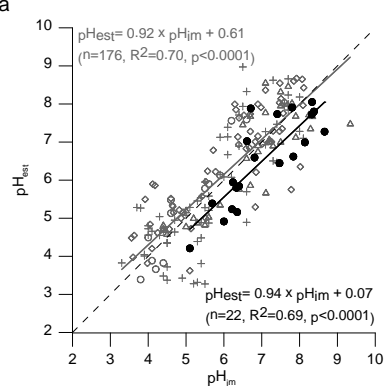

C

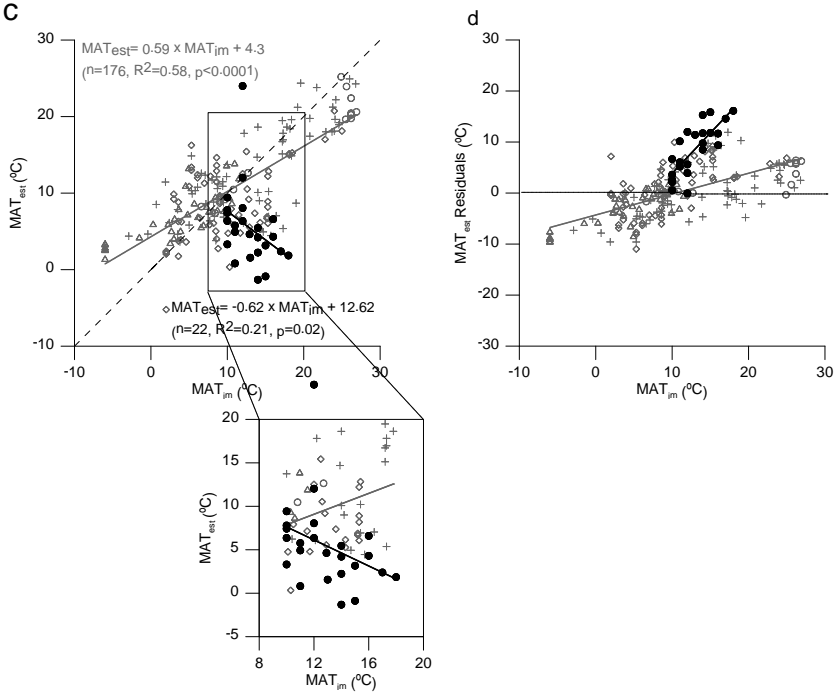

b

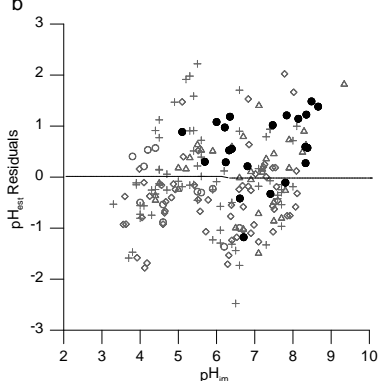

Fig. 3. Linear regression plots of (a) measured soil $\mathrm{pH}\left(\mathrm{pH}_{\mathrm{im}}\right)$ vs. estimated $\mathrm{pH}$ ( $\mathrm{pH}_{\mathrm{est}}$ ), (b) $\mathrm{pH}_{\mathrm{im}}$ vs. $\mathrm{pH}_{\mathrm{est}}$ residuals, (c) instrumentally measured mean annual temperature $\left(\mathrm{MAT}_{\mathrm{im}}\right)$ vs. estimated

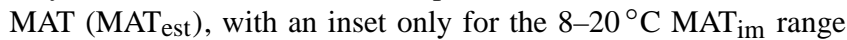
found in the samples from the Iberian Peninsula, (d) MAT $_{\text {im }}$ vs. MAT $_{\text {est }}$ residuals. Data compiled by Peterse et al. (2012) are plotted in grey and distinguished by symbols as follows: Weijers et al. (2007) (+), Peterse et al. (2012) $(\diamond)$, Bendle et al. (2010) $(\bigcirc)$ and Peterse et al. (2009b) $(\Delta)$. Data from this study are shown in black $(\bullet)$. Linear regression lines and equations, $R^{2}$, and $p$ values are shown in grey for the Peterse et al. (2012) data set and in black for the present study. The dashed line is drawn for illustration purposes to indicate a $1: 1$ relationship.

correlated showing a similar slope $(-0.33)$ to the one determined in global calibration data sets $(-0.35$, Weijers 2007 ; Peterse 2012; Fig. 2a). However, CBT values are not cor-

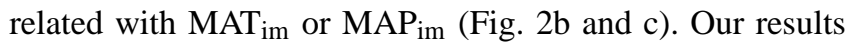
would then confirm the CBT relationship with $\mathrm{pH}$. This is in contrast to previous studies that suggested that the calibration of soils above $\mathrm{pH} 7$ needed to be revised (Loomis et al. 2011; Weijers et al. 2007). We also observed a significant correlation between $\mathrm{pH}_{\mathrm{im}}$ and MBT' values $\left(R^{2}=0.71\right.$, $p<0.0001$ ), which is even higher than the one observed in the global data set (Fig. 2d). As previous studies indicated that the variation in the MBT index is mostly explained by differences in soil $\mathrm{pH}$ and temperature (Weijers et al.,

2007), we further compared MBT' of our samples to $\mathrm{MAT}_{\text {im }}$ (Fig. 2e).

The range in MBT' values in the Spanish data set is similar to the one observed for the global data set (Peterse et al., 2012) despite a much narrower range of $\mathrm{MAT}_{\mathrm{im}}$ in our Iberian samples $\left(10-18^{\circ} \mathrm{C}\right.$; Table 1 and Fig. 2e). However, the relative abundance of methyl brGDGTs increases at higher temperatures in the Iberian samples. Thus, MBT' and $\mathrm{MAT}_{\mathrm{im}}$ show a weak but significant negative correlation within the Spanish sample set $\left(R^{2}=0.21 ; p=0.02\right)$ in contrast to the positive correlation between MBT and MAT observed by Weijers et al. (2007) and Peterse et al. (2012) for a global data set (Fig. 2e).

The MBT'/CBT values in the Iberian soils translate (using Eq. 5) to a MAT est $_{\text {of }}-0.9$ to $9.4^{\circ} \mathrm{C}$ and an average of $4.7^{\circ} \mathrm{C}$ (Table 1). These estimated values are lower than the climatic atlas temperatures, which yields monthly air temperatures in the sample sites from 3 to $23^{\circ} \mathrm{C}$ and annual mean values (i.e., $\mathrm{MAT}_{\mathrm{im}}$ ) from 10 to $18^{\circ} \mathrm{C}$. It is also noteworthy that the residuals of $\mathrm{MAT}_{\text {est }}$ are not randomly distributed, since MBT'/CBT-derived temperatures consistently underestimate $\mathrm{MAT}_{\mathrm{im}}$ in the Iberian data set (Fig. 3d). This deviation was observed previously in the global data set, but it is more pronounced in the Iberian soils (Fig. 3d). Thus, MBT'/CBT-derived temperatures ( $\mathrm{MAT}_{\text {est }}$ ) in 17 out of the 23 soil samples underestimate $\mathrm{MAT}_{\text {im }}$ by more than the $5{ }^{\circ} \mathrm{C}$ proxy calibration error found by Peterse et al. (2012; Fig. 3c, Table 1). For example, a soil sample close to the Zarracatín lagoon in the south of Spain (sample code ZA, Table 2), where monthly mean temperatures never fall below $11^{\circ} \mathrm{C}$ and $\mathrm{MAT}_{\mathrm{im}}$ is $18^{\circ} \mathrm{C}$, has a $\mathrm{MAT}_{\text {est }}$ value of $1.9^{\circ} \mathrm{C}$ (Table 1 ). Even if we were to attempt a regional temperature calibration of the MBT', the weak correlation between MBT' and MAT $_{i m}$ (Fig. 2e) would result in an error much higher than the $5^{\circ} \mathrm{C}$ reported for the global data set (Peterse et al., 2012). Moreover, local calibrations have already been proven not to improve MBT'/CBT-based MAT accuracy (Peterse et al., 2012).

These findings would suggest caution in the use of the MBT'/CBT for paleotemperature reconstructions in the Iberian Peninsula, and support previous studies that showed that environmental parameters other than temperature may control the distribution of brGDGTs (e.g., Weijers et al., 2011; Peterse et al., 2012; Dirghangi et al., 2013; Loomis et al., 2013). Some studies have attributed the lack of correlation between $\mathrm{MAT}_{\mathrm{im}}$ and MBT/CBT to factors such as vegetation change, soil type and changes in hydrologic regime (e.g., Weijers et al., 2011; Dirghangi et al., 2013; Loomis et al., 2013).

\subsection{Potential control of hydrological conditions on MBT'}

We observe significant correlations between $\mathrm{MAP}_{\mathrm{im}}$ and MBT' $\left(R^{2}=0.55, p<0.0001\right.$; Fig. $\left.2 \mathrm{f}\right)$. This is similar to 

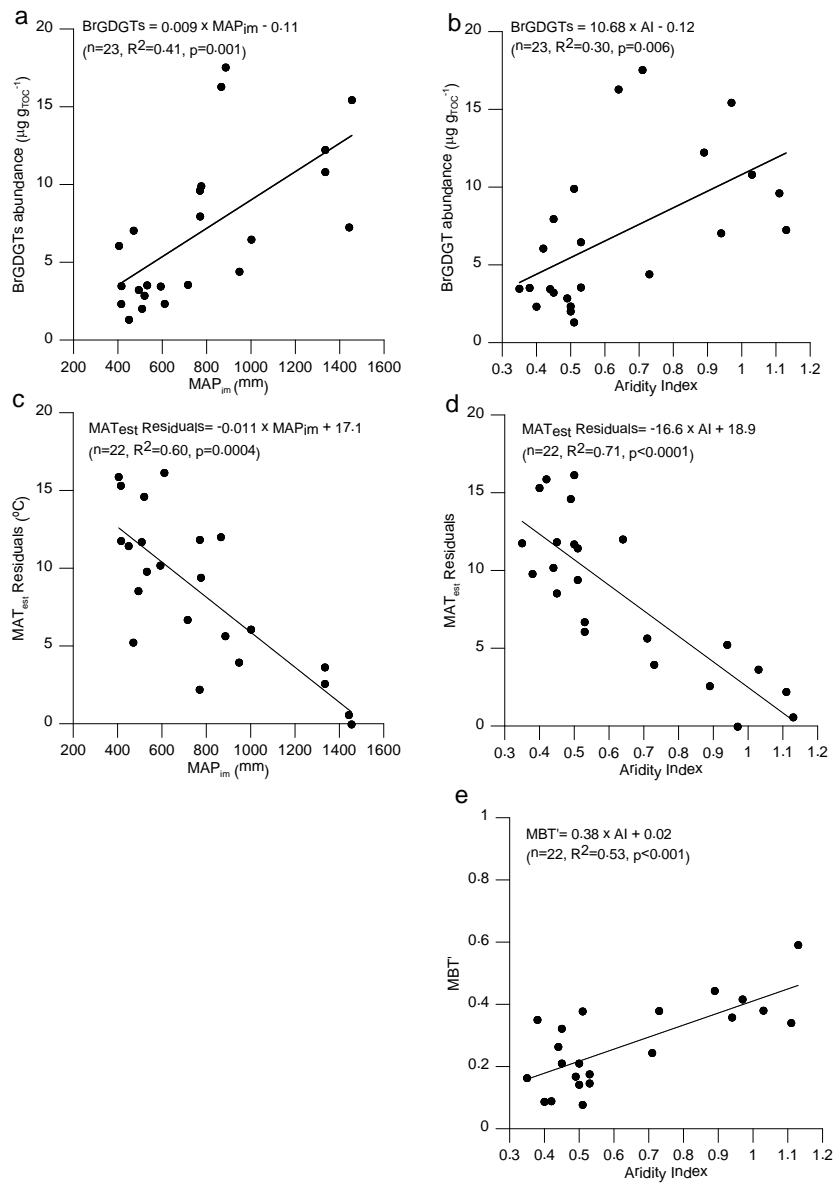

Fig. 4. Linear regression plots of (a) brGDGT concentration in soils normalized to total organic carbon (TOC) vs. values of instrumentally measured mean annual precipitation $\left(\mathrm{MAP}_{\mathrm{im}}\right)$ (b) brGDGT concentration normalized to TOC vs. aridity index (AI), (c) MAP im vs. estimated mean annual temperature $\left(\mathrm{MAT}_{\mathrm{est}}\right)$ residuals and $(\mathbf{d})$ AI vs. $\mathrm{MAT}_{\text {est }}$ residuals, (e) AI vs. MBT'.

the observation from the global data set (Weijers et al. 2007; Peterse et al. 2012) where the MBT/CBT vs. $\mathrm{MAP}_{\text {im }}$ correlation was interpreted as the result of covariation between temperature and precipitation (Weijers et al. 2007). Indeed in tropical sites higher precipitation is often associated with higher temperatures, but in arid regions, such as the southern Iberian Peninsula, the highest temperatures are usually found in the driest areas, not the wettest. In fact, in the Iberian soil data set we find a weak inverse correlation between $\mathrm{MAP}_{\mathrm{im}}$ and $\mathrm{MAT}_{\mathrm{im}}\left(\mathrm{MAT}_{\mathrm{im}}=-0.0004 \mathrm{MAP}_{\mathrm{im}}+16\right.$, $R^{2}=0.32, p=0.017$ ). Thus, our results suggest that sitespecific water availability may influence MBT' in the Iberian soils. This would be in agreement with previous studies that also suggested an effect of either precipitation or water content on the MBT in North American and Tibetan soils (Dirghangi, 2013; Wang et al., 2013). Peterse et al. (2012) also suggested an effect of precipitation on the MBT' index because the addition of temperate soil data to the global data set increased the scatter of the original MBT/CBT calibration (Weijers et al., 2007). The global MBT' values from Peterse et al. (2012) show indeed a large scatter in the $8-20^{\circ} \mathrm{C}$ range (Fig. $3 \mathrm{c}$ inset), and the $R^{2}$ of the MBT' vs. $\mathrm{MAT}_{\mathrm{im}}$ correlation is only 0.09 , much lower than the $R^{2}$ of $0.58 \mathrm{ob}-$ served for the full -8 to $28^{\circ} \mathrm{C}$ range of the global data set (Fig. 3c). Therefore, MBT' correlates poorly with MAT $_{\text {im }}$ in the temperate range, in which the Iberian Peninsula soil samples fall (Fig. 3c), regardless of the study area, and this should be taken into account in future regional studies.

Interestingly, the brGDGT abundances normalized to TOC (Fig. 4a), the MBT' (Fig. 2f), and the MAT ${ }_{\text {est }}$ residuals (Fig. 4c) are significantly correlated with $\mathrm{MAP}_{\text {im }}$. This may indicate that under water stress the brGDGT-producing organisms are less productive and may have to adapt their membranes to water availability rather than temperature, resulting in the observed underestimation of MAT (Fig. 3d). Our data show that brGDGT abundances are lower under dryer (Table 2) and potentially oxic conditions, as has been shown in previous studies (e.g., Dirghangi et al., 2013; Wang et al., 2013). The physiological influence of changes in hydrological conditions on the degree of methylation of the brGDGTs is not yet known. It is possible that precipitation has an indirect influence on MBT' as the amount of precipitation can affect soil $\mathrm{pH}$ due to increased leaching of calcium and magnesium (Brady and Weil, 2002). Additionally, rainwater has a slightly acidic $\mathrm{pH}$ of 5.7 due to the dissolution of atmospheric $\mathrm{CO}_{2}$ (Brady and Weil, 2002). But no correlation was observed between $\mathrm{CBT}\left(\right.$ or $\left.\mathrm{pH}_{\mathrm{im}}\right)$ and $\mathrm{MAP}_{\mathrm{im}}$ at the investigated sites (Fig. 2c). Hence, a possible effect of precipitation on soil $\mathrm{pH}$ cannot explain the correlation between MBT' or MAT $_{\text {est }}$ residuals and MAP $_{\text {im. }}$. Alternatively, as precipitation is only one expression of hydrological conditions at a site, MBT' may also be influenced by soil type, vegetation and water circulation through percolation and evaporation.

Water availability is critical in semiarid soils affecting osmotic status and abundance of microbial cells as well as nutrient cycling (Bustamante et al., 2012, and references therein). In order to better estimate water availability, we used the aridity index (AI), a measure for moisture availability in soils excluding the specific impact of soil condition to adsorb and hold water (Trabucco and Zomer, 2009). The AI is a ratio of MAP and mean annual potential evaporation, and increases with more humid conditions (see Trabucco and Zomer, 2009, for details). It was calculated for each site using the approach followed by the Consortium for Spatial Information (CGIAR-CSI) based on United Nations Environment Programme (UNEP) criteria (Tables 1 and 2; Trabucco and Zomer, 2009). In the Iberian soils the brGDGT abundance shows a weak, albeit significant correlation with the $\mathrm{AI}\left(R^{2}=0.30, p=0.006\right.$; Fig. $\left.4 \mathrm{~b}\right)$, but the $\mathrm{AI}$ has a much higher correlation with the $\mathrm{MAT}_{\text {est }}$ residuals $\left(R^{2}=0.71, p<0.0001\right.$; Fig. 4 d $)$. In fact, the AI can explain $71 \%$ of the variance in the residuals (Fig. 4d), and $53 \%$ 
of the variance in the MBT' index $\left(\mathrm{MBT}^{\prime}=0.38 \mathrm{AI}+002\right.$, $n=22, R^{2}=0.53, p<0.001$; Fig. 4e). MAP $_{\text {im }}$ also explains $55 \%$ of the variance in the MBT' index but only $60 \%$ in the $\mathrm{MAT}_{\text {est }}$ residuals (Fig. 4c). This suggests that it is the soil's capacity to retain water, or soil moisture, rather than just precipitation that drives MBT' besides temperature and $\mathrm{pH}$. Correlations between the MBT' and MAP have already been reported (Huguet et al., 2010a; Loomis, 2011; Dirghangi et al., 2013), but the validity of the correlation between MBT' and $\mathrm{AI}$ (Fig. 4e) has to be confirmed by analyzing brGDGTs in a larger number of soils. As mentioned above, the AI cannot explain all the variation observed in the MBT' (only 53\%, Fig. 4e), and other factors such as vegetation type or soil water retention capacity that also affect water availability most probably play a role. In fact vegetation type has already been shown to affect the MAT $_{\text {est }}$ values in North American soils (Weijers et al., 2011).

Our results have significant implications for the interpretation of paleotemperature records derived from the combined MBT' and CBT indices. Based on our analysis, we urge caution in the application of the proxy in arid environments and areas with an aridity index lower than 0.8 , as we observe that $\mathrm{MAT}_{\text {est }}$ accuracy in such locations is likely to be low, and with an error larger than the one provided in the global MBT'/CBT vs. MAT calibration (Peterse et al., 2012). The exact hydrological threshold below which water availability exerts a stronger control on the MBT' index than temperature will have to be determined in future studies. We recommend that hydrological conditions should be evaluated in conjunction with MBT'/CBT paleotemperatures in paleoreconstruction studies, for example through known paleohydrological proxies such as compound-specific $\delta \mathrm{D}$ values, whose analysis can even be carried out on the same lipid extracts (e.g. Sachse et al., 2012).

\section{Conclusions}

In soils from the Iberian Peninsula, the CBT index was shown to co-vary with soil $\mathrm{pH}$ with sufficient accuracy to confirm its use as a proxy for estimating paleo-soil $\mathrm{pH}$ in the region. The MBT' index was also shown to relate to soil $\mathrm{pH}$, but the expected relation between MBT' and mean annual air temperatures $\left(\mathrm{MAT}_{\mathrm{im}}\right)$ was not apparent. Due to these results, the application of the combined MBT' and CBT indices to estimate air temperatures does not seem appropriate in the Iberian Peninsula.

In contrast, the MBT' index was coupled with instrumental mean annual precipitation $\left(\mathrm{MAP}_{\mathrm{im}}\right)$ and the aridity index (a ratio of MAP and mean annual potential evaporation). We thus argue that, under moisture shortage, MBT' is not coupled to temperature and is instead controlled by soil water availability. The validity of the correlation between MBT' and AI as well as the AI threshold below which MBT' might be biased needs to be contrasted in other soil types and study areas. Nonetheless, we suggest that these findings should be taken into account when interpreting MBT'/CBT climatic records from arid areas.

Acknowledgements. We want to thank Ferran Colomer Ventura and Pau Comes for TOC \% measurements and sampling map. Núria Moraleda and Gemma Rueda are thanked for technical assistance. We also thank Sinninghe-Damsté and three anonymous reviewers for helping to improve this manuscript. This work was financed through awards CGL2010-15000 to A. Rosell-Melé and Juan de la Cierva fellowships to C. Huguet and S. Fietz from Ministerio de Economía y Competitividad. The work leading to these results has received funding from the European Union Seventh Framework Programme (FP7/2007-2013) under grant agreement no. 252659 .

Edited by: A. Neftel

\section{References}

Ayari, A., Yang, H., Wiesenberg, G. L. B., and Xie, S.: Distribution of archaeal and bacterial tetraether membrane lipids in rhizosphere-root systems in soils and their implication for paleoclimate assessment, Geochem. J., 47, 337-347, 2013.

Blaga, C. I., Reichart, G. J., Heiri, O., and Sinninghe Damsté, J. S.: Tetraether membrane lipid distributions in water-column particulate matter and sediments: a study of 47 European lakes along a north-south transect, J. Paleolimnol., 41, 523-540, 2009.

Blaga, C. I., Reichart, G. J., Schouten, S., Lotter, A. F., Werne, J. P., Kosten, S., Mazzeo, N., Lacerot G., and Sinninghe Damsté, J. S.: Branched glycerol dialkyl glycerol tetraethers in lake sediments: Can they be used as temperature and $\mathrm{pH}$ proxies?, Organ. Geochem., 41, 1225-1234, 2010.

Brady, N. C. and Weil, R. R.: The Nature and Properties of Soils, 13th edition, Prentice Hall, Upper Saddle River, New Jersey, 960 pp., 2002.

Bustamante, M. M. C. Nardoto, G. B., Pinto, A. S., Resende, J. C. F., Takahashi, F. S. C., and Vieira, L. C. G.: Potential impacts of climate change on biogeochemical functioning of Cerrado ecosystems, Brazil. J. Biol., 72, 655-671, 2012.

Colinvaux, P. A., DeOliveira, P. E., Moreno, J. E., Miller, M. C., Bush, M. B.: A long pollen record from lowland Amazonia: Forest and cooling in glacial times, Science, 274, 85-88, 1996.

Dirghangi S. S., Pagani, M., Hren, M. T., and Tipple, B. J.: Distribution of glycerol dialkyl glycerol tetraethers in soils from two environmental transects in the USA, Organ. Geochem., 59, 4960, 2013

Escala, M., Fietz, S., Rueda, G., and Rosell-Melé, A.: Analytical Considerations for the Use of the Paleothermometer Tetraether Index(86) and the Branched vs Isoprenoid Tetraether Index Regarding the Choice of Cleanup and Instrumental Conditions, Anal. Chem., 81, 2701-2707, 2009.

Fietz, S., Martinez-Garcia, A., Huguet, C., Rueda, G., and RosellMele, A.: Constraints in the application of the Branched and Isoprenoid Tetraether index as a terrestrial input proxy, J. Geophys. Res.-Oceans., 116, doi:10.1029/2011JC007022, 2011.

Heiri, O., Lotter, A. F., and Lemcke, G.: Loss on ignition as a method for estimating organic and carbonate content in sediments: reproducibility and comparability of results, J. Paleolimnol., 25, 101-110, 2001. 
Huguet C., Hopmans E. C., Febo-Ayala W., Thompson D. H., Sinninghe Damsté J. S., Schouten S.: An improved method to determine the absolute abundance of glycerol dibiphytanyl glycerol tetraether lipids, Organ. Geochem., 37, 1036-1041, 2006.

Huguet, A., Fosse, C., Laggoun-Defarge, F., Toussaint, M.-L., and Derenne, S.: Occurrence and distribution of glycerol dialkyl glycerol tetraethers in a French peat bog, Organ. Geochem., 41, 559-572, 2010a.

Huguet, C., Martens-Habbena, W., Urakawa, H., Stahl, D. A., and Ingalls, A. E.: Optimization of extraction methods for intact and core glycerol dialkyl glycerol tetraethers (GDGTs), Limnol. Oceanogr. Meth., 8, 127-145, 2010 b.

Huguet, A., Wiesenberg, G. L. B., Gocke, M., Fosse, C., and Derenne, S.: Branched tetraether membrane lipids associated with rhizoliths in loess: Rhizomicrobial overprinting of initial biomarker record, Organ. Geochem., 43, 12-19, 2012.

Kurek, J., Cwynar, L. C., Ager, T. A., Abbott, M. B., and Edwards, M. E.: Late Quaternary paleoclimate of western Alaska inferred from fossil chironomids and its relation to vegetation histories, Quat. Sci. Rev., 28, 799-811, 2009.

Loomis, S. E., Russell, J. M., and Damste, J. S. S.: Distributions of branched GDGTs in soils and lake sediments from western Uganda: Implications for a lacustrine paleothermometer, Organ. Geochem., 42, 739-751, 2011.

Lotter, A. F., Birks, H. J. B., Hofmann, W., and Marchetto, A.: Modern diatom, cladocera, chironomid, and chrysophyte cyst assemblages as quantitative indicators for the reconstruction of past environmental conditions in the Alps, 1. Climate, J. Paleolimnol., 18, 395-420, 1997.

Marlowe, I. T., Green, J. C., Neal, A. C., Brassell, S. C., Eglinton, G., and Course, P. A.: Long-chain (N-C37-C39) alkenones in the Prymnesiophyceae - distribution of alkenones and other lipids and their taxonimic significance, Brit. Phycol. J., 19, 203-216, 1984.

Ninyerola M., Pons X., and Roure J. M.: Atlas climático digital de la Península Ibérica. Metodología y aplicaciones en bioclimatología y geobotánica. Universitat Autònoma de Barcelona, Bellaterra, 2005.

Oppermann, B. I., Michaelis, W., Blumenberg, M., Frerichs, J., Schulz, H. M., Schippers, A., Beaubien, S. E., and Krueger, M.: Soil microbial community changes as a result of long-term exposure to a natural $\mathrm{CO} 2$ vent, Geochimica Et Cosmochimica Acta, 74, 2697-2716, 2010.

Peterse, F., Schouten, S., van der Meer, J., van deer Meer, M. T. J., and Sinninghe Damsté, J. S.: Distribution of branched tetraether lipids in geothermally heated soils: implications for the MBT/CBT temperature proxy, Organ. Geochem., 40, 201-205, 2009a.

Peterse, F., Schouten, F., Fierer, N., Jackson, R. B., Nicol, G. W., Weijers, J. W. H., van Groeningen, K. J., Wiesenberg, G. L. B., Jia, G., and Sinninghe Damsté, J. S.: Environmental controls on the bacterial tetraether membrane lipid distribution in soils: implications for the MBT/CBT temperature proxy. In: 24th Internationa Meeting on Organ. Geochem., Bremen, Germany, p. 72 (abstract), 2009b.

Peterse, F., Nicol, G. W., Schouten, S., and Sinninghe Damsté, J. S.: Influence of soil $\mathrm{pH}$ on the abundance and distribution of core and intact polar lipid-derived branched GDGTs in soil, Organ. Geochem., 41, 1171-1175, 2010.
Peterse, F., Meer, J., van der, Schouten, S., Weijers, J. W. H., Fierer, N., Jackson, R. B., Kim, J.-H., and Sinninghe Damsté, J. S.:, Revised calibration of the MBT-CBT paleotemperature proxy based on branched tetraether membrane lipids in surface soils, Geochimica Et Cosmochimica Acta, 96, 215-229, 2012.

Powers, L. A., Werne, J. P., Johnson, T. C., Hopmans, E. C., Sinninghe Damsté, J. S., and Schouten, S.: Crenarchaeotal membrane lipids in lake sediments: A new paleotemperature proxy for continental paleoclimate reconstruction?, Geology, 32, 613616, 2004.

Powers, L., Werne, J. P., Vanderwoude, A. J., Sinninghe Damsté, J.S., Hopmans, E. C., and Schouten, S.: Applicability and calibration of the TEX86 paleothermometer in lakes, Organ. Geochem., 41, 404-413, 2010.

Rethore, G., Montier, T., Le Gall, T., Delepine, P., Cammas-Marion, S., Lemiegre, L., Lehn, P., and Benvegnu, T.: Archaeosomes based on synthetic tetraether-like lipids as novel versatile gene delivery systems, Chem. Communicat., 28, 2054-2056, 2007.

Rueda, G., Rosell-Melé, A., Escala, M., Gyllencreutz, R., and Backman, J.: Comparison of instrumental and GDGT-based estimates of sea surface and air temperatures from the Skagerrak, Organ. Geochem., 40, 287-291, 2009.

Sachse, D., Billault, I., Bowen, G. J., Chikaraishi, Y., Dawson, T. E., Feakins, S. J, Freeman, K. H., Magill, C. R., McInerney, F. A., van der Meer, M. T. J., Polissar, P., Robins, R. J., Sachs, J. P., Schmidt, H.-L., Sessions, A. L., White, J. W. C., West, J. B., and Kahmen, A.: Molecular Paleohydrology: Interpreting the Hydrogen- Isotopic Composition of Lipid Biomarkers from Photosynthesizing Organisms, in: Annual Review of Earth and Planetary Sciences, edited by: Jeanloz, R., Ann. Rev. Earth Planet. Sci., 40, 221-249, 2012.

Schouten, S., Huguet, C., Hopmans, E. C., Kienhuis, M. V. M., and Sinninghe Damsté, J. S.: Analytical methodology for TEX 86 paleothermometry by highperformance liquid chromatography/atmospheric pressure chemical ionization-mass spectrometry, Anal. Chem., 79, 2940-2944, 2007.

Sinninghe-Damsté, J. S., Rijpstra, W. I. C., Hopmans, E. C., Weijers, J. W. H., Foesel, B. U., Overmann, J., and Dedysh, S. N.: 13,16-Dimethyl Octacosanedioic Acid (iso-Diabolic Acid), a Common Membrane-Spanning Lipid of Acidobacteria Subdivisions 1 and 3, Appl. Environ. Microbiol., 77, 4147-4154, 2011.

Soil Atlas of Europe, European Soil Bureau Network European Commission, Office for Official Publications of the European Communities, 2995 Luxembourg, 128 pp., 2005.

Soil Survey Staff: Keys to Soil Taxonomy (Eleventh ed.), United States Department of Agriculture, Natural Resources Conservation Service, 338 pp., 2010.

Sun, Q., Chu, G., Liu, M., Xie, M., Li, S., Ling, Y., Wang, X., Shi, L., Jia, G., and Lu, H.: Distributions and temperature dependence of branched glycerol dialkyl glycerol tetraethers in recent lacustrine sediments from China and Nepal, J. Geophys. Res., 116, G01008, doi:10.1029/2010JG001365, 2011.

Thomas, G. W.: Soil pH and soil acidity. In: J.M. Bartels, (Ed) Methods of soil analysis, Part 3 Chemical methods. SSSA Books series: 5 SSSA, Madison, WI, 1996.

Tierney, J. E., Russell, J. M., Eggermont, H., Hopmans, E. C., Verschuren, D., and Sinninghe Damsté, J. S.: Environmental controls on branched tetraether lipid distributions in tropical East African 
lake sediments. Geochimica et Cosmochimica Acta, 74, 49024918, 2010.

Toney, J. L. Huang, Y. S., Fritz, S. C., Baker, P. A., Grimm E., and Nyren P.: Climatic and environmental controls on the occurrence and distributions of long chain alkenones in lakes of the interior United States, Geochimica Et Cosmochimica Acta, 74, 15631578, 2010.

Trabucco, A. and Zomer, R. J.: Global Aridity Index (GlobalAridity) and Global Potential Evapo-Transpiration (Global-PET) Geospatial Database. CGIAR Consortium for Spatial Information, Published online, availabl at: http://www.csi.cgiar.org, 2009.

UNEP: United Nations Environment Program, World Atlas of Desertification, 2nd Edn. UNEP, London, 1997.

Wang, H. Y., Liu, W. G., Zhang, C. L. L., Liu, Z. H., He, Y. X.: Branched and isoprenoid tetraether (BIT) index traces water content along two marsh-soil transects surrounding Lake Qinghai: Implications for paleo-humidity variation, Organ. Geochem., 59, 75-81, 2013.

Weijers, J. W. H., Bernhardt, B., Peterse, F., Werne, J. P., Dungait, J. A. J., Schouten S., and Sinninghe Damsté, J. S.: Absence of seasonal patterns in MBT-CBT indices in mid-latitude soils, Geochimica Et Cosmochimica Acta, 75, 3179-3190, 2011.

Weijers, J. W. H., Wiesenberg, G. L. B., Bol, R., Hopmans, E. C., and Pancost, R. D.: Carbon isotopic composition of branched tetraether membrane lipids in soils suggest a rapid turnover and a heterotrophic life style of their source organism(s), Biogeosciences, 7, 2959-2973, doi:10.5194/bg-7-2959-2010, 2010.
Weijers, J. W. H., Schouten, S., van den Donker, J. C., Hopmans, E. C., and Sinninghe Damsté, J. S.: Environmental controls on bacterial tetraether membrane lipid distribution in soils, Geochimica Et Cosmochimica Acta, 71, 703-713, 2007.

Weijers, J. W. H., Schouten, S., Hopmans E. C., Geenevasen, J. A. J., David, O. R. P., Coleman, J. M., Pancost, R. D., and Sinninghe Damsté, J. S.: Membrane lipids of mesophilic anaerobic bacteria thriving in peats have typical archaeal traits, Environ. Microbiol., 8, 648-657, 2006.

Werner, R. A, Bruch, B. A., and Brand, W. A.: ConFlo III - An interface for high precision delta(13)C and delta(15)N analysis with an extended dynamic range, Rapid Communications in Mass Spectrometry, 13, 1237-1241, 1999.

Yang, H., Ding W. H., Wang J.-X., Jin C.-S., He G.-Q., Qin Y.M.,and Xie S.-C.: Soil pH impact on microbial tetraether lipids and terrestrial input index (BIT) in China, Scince China, Earth Sci., 54, 1-10, 2011.

Zink, K. G., Leythaeuser, D., Melkonian, M., and Schwark, L.: Temperature dependency of long-chain alkenone distributions in Recent to fossil limnic sediments and in lake waters, Geochimica Et Cosmochimica Acta, 65, 253-265, 2001. 